\title{
Differences in aggressive behavior of male and female students using Rasch stacking
}

\author{
Alizamar $^{1 *}$, Yuda Syahputra ${ }^{1}$, Afdal $^{1}$, Zadrian Ardi $^{1}$, Leviana Trizeta ${ }^{1}$ \\ ${ }^{1}$ Universitas Negeri Padang, Indonesia \\ *Corresponding author, e-mail: alizamar@konselor.org
}

\begin{abstract}
Aggressive behavior that occurs among students nowadays indicates a decrease in the quality of education. One of the things that cause this is education which only emphasizes cognitive quality without being balanced with affective. This study aims to describe the differences in aggressive behavior between male and female students in Junior High School of West Sumatera. The sample consisted of 360 students (159 male and 201 female) spread across eight Junior High Schools in West Sumatera. The analysis technique used is the independent sample t-test combined with stacking RASCH model. The analysis show that in general there are differences in aggressive behavior between male and female students. The discussion regarding guidance and counseling services was further explained.
\end{abstract}

Keywords: Aggressive Behavior, Student, Gender Differences

How to Cite: Alizamar, A., Syahputra, Y., Afdal, A., Ardi, Z., \& Trizeta. L. (2019). Differences in aggressive behavior of male and female students using Rasch stacking. International Journal of Research in Counseling and Education, 3 (1): pp. 22-32. DOI: https://doi.org/10.24036/0051za0002

\section{Introduction}

Aggressive behavior in Indonesia as a case of violence has increased since 1998 with the death toll of 11,160 victims (Dewi, Prihatsanti, Setyawan, \& Siswati, 2015). Violence is a concern for all parties, especially in education which is keep increasing lately. The Indonesian Child Protection Commission (KPAI) explained that perpetrators of violence in the school were the closest people to victims of violence, namely those carried out by teachers amounting to $29.9 \%$, conducted by classmates at $42.1 \%$, and those made by classmates as much as $28 \%$. The violence that occurs in the world of education today is the impact of unbalanced education, which only emphasizes the cognitive achievement and lack of affective development (Assegaf, 2004).

Aggressive behavior is any form of action that is intended to hurt others physically and mentally (Berkowitz, 2005; Buss \& Perry, 1992; Taylor, Peplau, \& Sears, 2009). Aggression can also be explained in two types: reactive aggression and proactive aggression (Card \& Little, 2006; Fite, Stoppelbein, \& Greening, 2009). Reactive aggression refers to acts of provocation by other people to generate anger and frustration (Berkowitz, 2005). Whereas proactive aggression is not accompanied by anger, but as a means to achieve a goal (Berkowitz, 2005). Proactive aggression is also closely related to social learning theory derived from learning outcomes or the results of imitation (Bandura, 1973; Polman, 2008).

Some studies show that aggressive behavior does not arise by itself but is caused by the difficulty of building relationships with peers (Kim \& Nho, 2017), parental supervision of children (J. Lee \& Randolph, 2015; Van der Graaff, Branje, De Wied, \& Meeus, 2012), affected violent video games and movies (Fischer, Kastenmüller, \& Greitemeyer, 2010; Hasan, Bègue, Scharkow, \& Bushman, 2018; Jerabeck \& Ferguson, 2013), instability of self-esteem (E. J. Lee, 2014), lacko of self-control (Denson, DeWall, \& Finkel, 2012), excessive alcohol consuming (Denson et al., 2011; Keller, Blincoe, Gilbert, \& Haak, 2014; Koeswara, 1998), frustration and stress yang berlebihan(Koeswara, 1998; Tull, Jakupcak, Paulson, \& Gratz, 2007), patterns foster parents who are hard (Arifin, 2015; Casselman \& Rosenbaum, 2014; Goldstein, 2016; Willis, 2010), provocation from others (Arifin, 2015; Koeswara, 1998; Taylor et al., 2009), regulation of maladaptive emotions (Debono et al., 2016; Roll, J., Koglin, U., \& Petermann, 2012), and environments that are not conducive (Arifin, 2015; Berkowitz, 2005; Harris, 1996; Koeswara, 1998; Park, 2006; Willis, 2010). 
Regarding the difference in aggressive behavior, the results found that differences in terms of gender were also related to forms of aggressive behavior. Male students tend to do physical and verbal behavior directly, while female students do aggressive actions indirectly (Assegaf, 2004). While other studies show male students in general are in the moderate category and female students in the low category (Aulya, Ilyas, \& Ifdil, 2016). While research in China showed $32.3 \%$ of men committed aggressive behavior and $13.3 \%$ of female (Ko, Yen, Liu, Huang, \& Yen, 2009). The need to identify the initial conditions of aggressive behavior of male and female students in junior high schools in West Sumatra. so that before developing a counseling service model to reduce the aggressive behavior of counselors or researchers, they can then use the data.

The purpose of this study is to identify the initial conditions of aggressive behavior based on the sex of junior high school students in West Sumatra, so that they can determine the steps to reduce aggressive behavior and can make the development of appropriate guidance and counseling service models.

\section{Method}

This study uses a quantitative approach with a descriptive comparative type (Creswell, 2013). The study sample amounted to 360 people, consisting of 159 male and 201 female spread across 8 junior high schools (public and private) in West Sumatra. The analysis technique used is the independent sample t-test combined with stacking model rasch. The data in this study are politomical data collected using an aggressive behavior instrument in the form of amodel Likertscale with five alternative answers.

Instrument is based on aggressive forms of behavior, namely: physical, verbal, anger and hostility (AbdEl-Fattah, 2007; Bryant \& Smith, 2001; Buss \& Perry, 1992; Reyna, Ivacevich, Sanchez, \& Brussino, 2011 ; Singh \& Singh, 2016; Værøy, 2013). Analysis of validity and reliability of instruments using Rasch models (Sumintono \& Widhiarso, 2015). Furthermore, it is stated in table 1 below.

Table 1 Reliability of 47 measured item

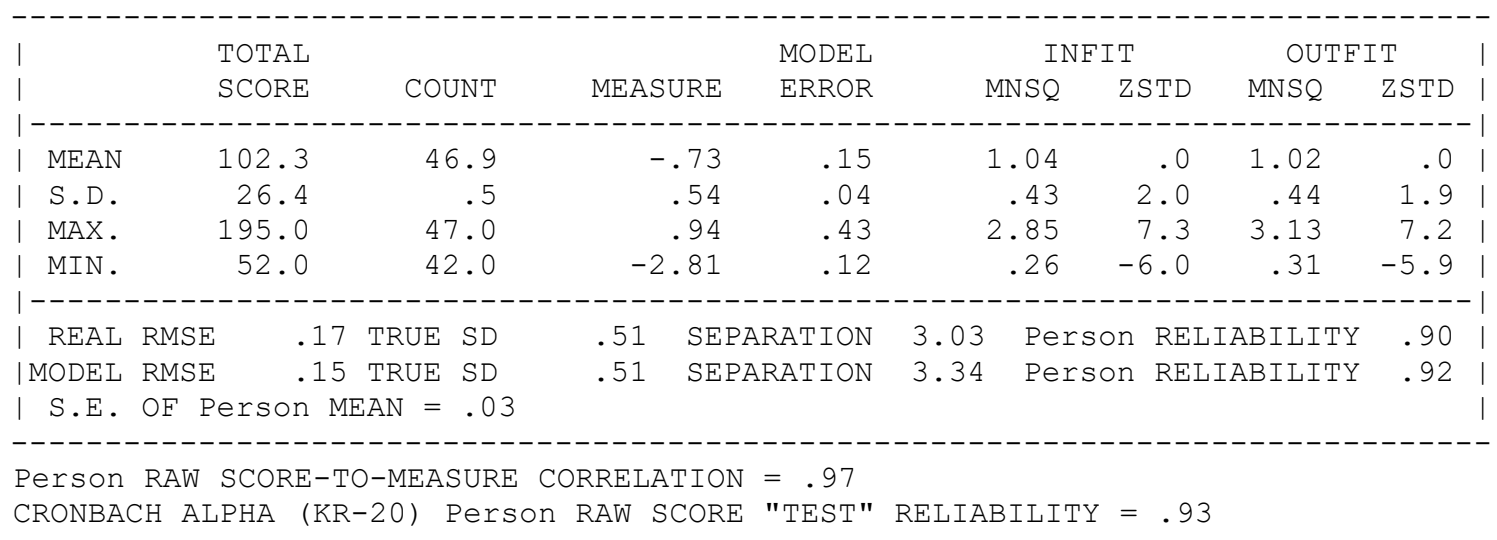

Table 2 Reliability of Item

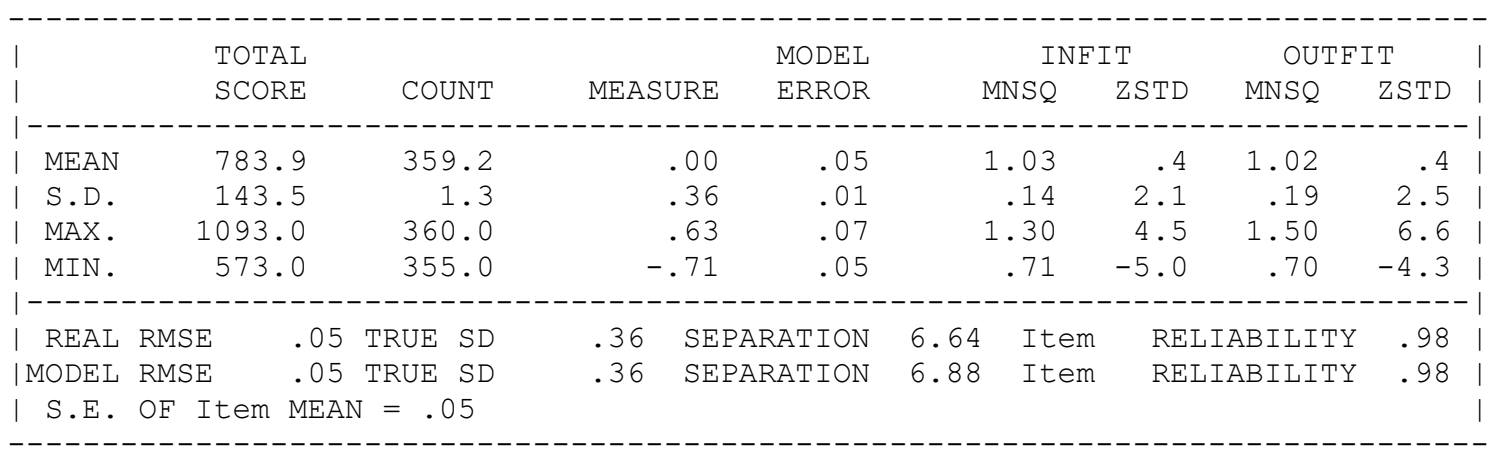

Table 1 the reliability of person is 0.90 , this shows that the consistency of the person in giving a good answer. Furthermore, the separation person value shows a value of 3.03, this shows three (3) groups of 
people, namely: high, medium and low. While the reliability of items in Table 2, can be seen the item reliability score is 0.98 , this shows that the quality of the items used in the measurement is special and the interaction between the person and the item shows good seen from the Alpha Cronbach value (KR-20) is 0.93 .

Validity analysis uses Principal Component Analysis (PCA) of residuals using 2 parameters, first the total raw variance in observation (minimum 20\%) and the two total raw unexplained variance values (minimum 15\%) (Linacre, 2011). Further is presented in Table 3 below.

Table 3 Standardized Residual Variance

\begin{tabular}{|c|c|c|c|c|}
\hline & -- Er & pirical & -- & Modeled \\
\hline Total raw variance in observations $=$ & 65.4 & $100.0 \%$ & & $100.0 \%$ \\
\hline Raw variance explained by measures = & 18.4 & $28.1 \%$ & & $30.5 \%$ \\
\hline Raw variance explained by persons= & 2.6 & $3.9 \%$ & & $4.3 \%$ \\
\hline Raw Variance explained by items= & 15.8 & $24.2 \%$ & & $26.2 \%$ \\
\hline Raw unexplained variance $($ total) $=$ & 47.0 & $71.9 \%$ & $100.0 \%$ & $69.5 \%$ \\
\hline Unexplned variance in 1 st contrast $=$ & 6.7 & $10.2 \%$ & $14.2 \%$ & \\
\hline Unexplned variance in 2 nd contrast $=$ & 3.0 & $4.6 \%$ & $6.4 \%$ & \\
\hline Unexplned variance in 3rd contrast $=$ & 1.9 & $3.0 \%$ & $4.1 \%$ & \\
\hline Unexplned variance in 4 th contrast $=$ & 1.7 & $2.6 \%$ & $3.6 \%$ & \\
\hline Unexplned variance in 5 th contrast $=$ & 1.7 & $2.6 \%$ & $3.6 \%$ & \\
\hline
\end{tabular}

Table 3 above, it appears that the total raw variance results are $28.1 \%$ not much different from the expected value of $30.5 \%$. This shows that the minimum unidimensional requirement of $20 \%$ has been fulfilled (Linacre, 2011). While the results of the unexplained variance are all ( 1 to 5 years) below $15 \%$ which indicates the level of independence of items in good instruments. Thus this condition states that the unidimensionality requirements of the instrument are met, furthermore it can be stated that the 47 items used are valid.

\section{Results and Discussion}

Discussion of the results of this study about (1) testing the differences in aggressive behavior of male and female students, (2) examining subvariable differences in male and female aggressive behavior which include: physical, verbal, anger, and hostility.

\section{Differences in Aggressive Behavior between Male and Female Students}

Aggressive behavior must be reduced in the world of education. At present, suspects who engage in aggressive behavior are not just male, but female participate in aggressive behavior towards their own friends. Furthermore the results of the analysis of the different test of the aggressive behavior of male and female students are presented in Table 4 below.

Table 4 Results of Independent Sample T-test for Aggressive Behavior in terms of Gender

\begin{tabular}{|c|c|c|c|}
\hline \multirow{2}{*}{ Value } & \multicolumn{2}{|c|}{ Lavene Test } & T-test \\
\hline & $\mathrm{F}$ & Sig. & Sig. (2-tailed) \\
\hline Aggressive Behavior & 1.410 & .236 & .001 \\
\hline
\end{tabular}

Table 4 above, shows the value of aggressive behavior ( $\operatorname{sig}=0.001$ ), these represent a p-value of $<0.05$, indicating there are differences in aggressive behavior among male and female. Many studies reveal that male are more aggressive than female, this is evidenced by the number of different studies with the same variables. Bandura strengthens the statement of male more aggressively than female through experimental research that male are more aggressive than female (Bandura, 1978). The results of cross-cultural research conducted by Whiting and Edward were put forward by (Segall, Berry, Poortinga, \& Dasen, 1999), in this study showing that male showed more angry expressions that were more dominant than female and male more respond aggressively. Gender differences in aggression do exist (Björkqvist, 2018), like research (Ticusan, 2014) reveals that in terms of aggressiveness there are some differences between male and female, the fact that male are more aggressive than female is very much noticed. Meta-analysis by cards through 
total aggression scores, generally male are more aggressive than female (Card, Stucky, Sawalani, \& Little, 2008).

Lei \& Li (2018) clarifies why male are more aggressive than female, from the results of these studies revealing authoritarian culture and parenting that shape male aggressive personalities rather than female, such as authoritarian children in Chinese culture, children male are fostered hard in Chinese culture rather than female who are nurtured with affection, because female are expected by parents and society to be obedient (Shi, Zhang, \& Huang, 2004). As a result, female are often less aggressive than male, regardless of the culture and style of care in their families (Frieze \& Li, 2010). In addition, male personalities are often unpleasant to others or more aggressive than female (Burton, Hafetz, \& Henninger, 2007). Based on the results of the above explanation about the differences in aggressive behavior, the researcher reinforced with a picture of the grouping of aggressive male and female behaviors presented in Figure 1.

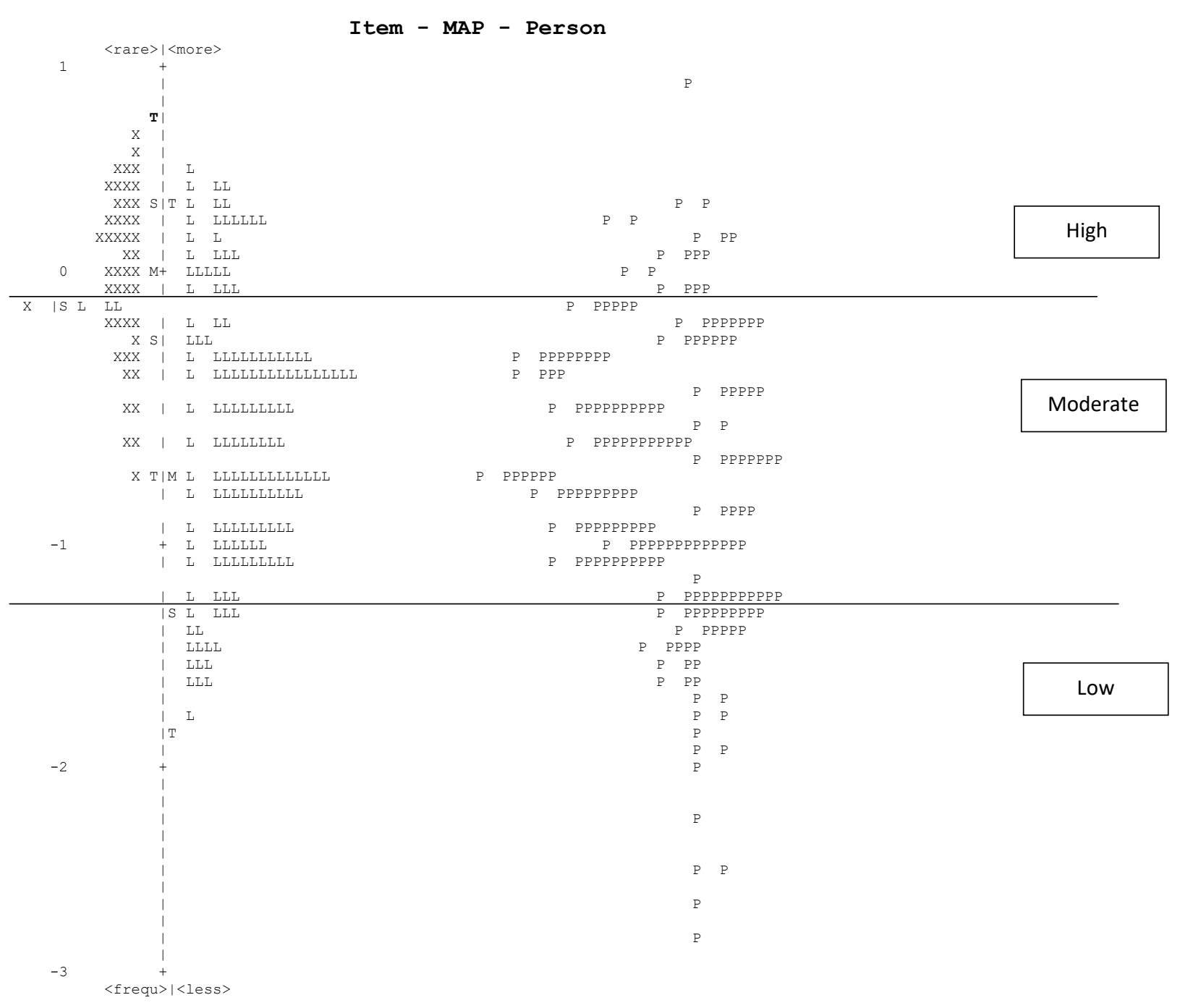

Figure 1. Difference in Grouping of Aggressive Behavior

Figure 1 shows men (L) are more aggressive than female (P). However, the tendency of male and female is in the moderate category. So that it is indicated that female also engage in aggressive behavior. As expressed by Baron \& Byrne (1994) about female who engage in aggressive behavior indirectly in verbal form (spreading gossip or isolating friends). Furthermore, the results of the explanation above are clarified by using a graph of students' ability to provide a response to the aggressive instruments presented in Figure 2 below.

Figure 2 shows the ability of female students tends to be higher than male in giving answers to 47 items. Clearly visible from the red line is more likely to be higher than the blue line in answering 47 items available on aggressive instruments. This indicates that female have self-regulation in restraining excessive emotions in themselves, and female have a higher empathy attitude towards others than male. 


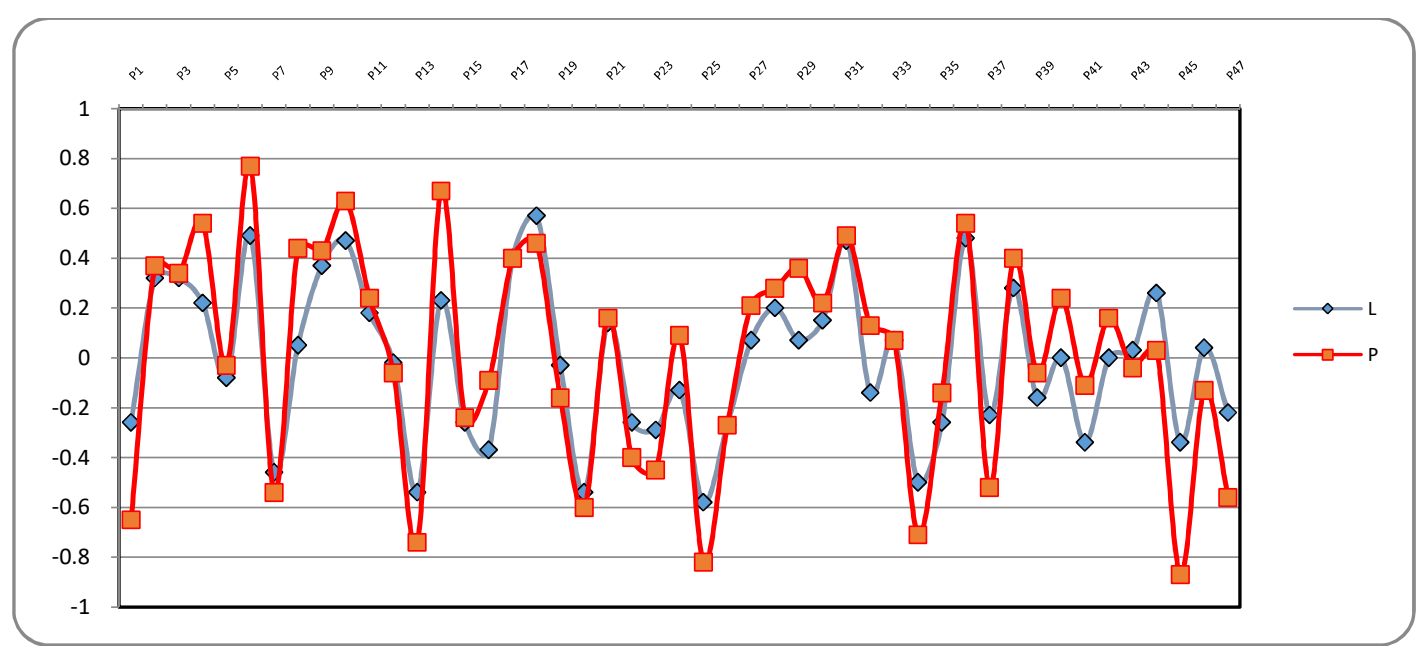

Figure 2. Differences in Aggressive Behavior of Male and Female Students

\section{Sub variable Differences of Aggressive Behavior between Male and Female Students}

Based on the results of the study, it can be described regarding subvariable aggressive behavior between male and female students. Further results of the description are presented in table 5 below

Table 5 Results of Independent Sample T-test Subvariable Aggressive Behavior in terms of Gender

\begin{tabular}{llcc}
\hline \multicolumn{1}{c}{$\begin{array}{c}\text { Subvariable of Aggressive } \\
\text { Behavior }\end{array}$} & Gender & Descriptive & T-test \\
\cline { 3 - 4 } & & Mean & Sig. (2-tailed) \\
\hline Physical & Male & 23.25 & .001 \\
& Female & 20.82 & \\
Verbal & Male & 47.04 & .001 \\
& Female & 42.60 & .008 \\
Anger & Male & 18.74 & \\
& Female & 17.12 & .147 \\
Hostility & Male & 18.81 & \\
& Female & 17.94 & \\
\hline
\end{tabular}

Table 5 above, shows the value of physically aggressive behavior ( $\operatorname{sig}=0.001$ ), verbal aggressive behavior $(\operatorname{sig}=0.001)$, aggressive behavior in anger $(\operatorname{sig}=0.008)$, this shows the results of all three subvariable forms of students' aggressive behavior showing differences, seen from the mean and significance of male students and female. Whereas hostile aggressive behavior has no difference, it can be seen from the mean and the results of significance (0.147). The above results support previous studies that explain male physical aggressiveness higher than female (Schober, Björkqvist, \& Somppi, 2009; Yuan et al., 2014). While female use non-verbal aggression more directly than male, and there is no difference between male and female in indirect aggression (Schober et al., 2009). Other studies reveal that male and female verbal aggression is almost the same, but male are more physically and female aggressively more indirect aggression (Björkqvist, 2018). Based on the results of the exposure above about subvariable differences in aggressive behavior, researchers reinforce the image on the grouping of the aggressive behavior of male and female are presented in figure $3,4,5$, and 6 . 


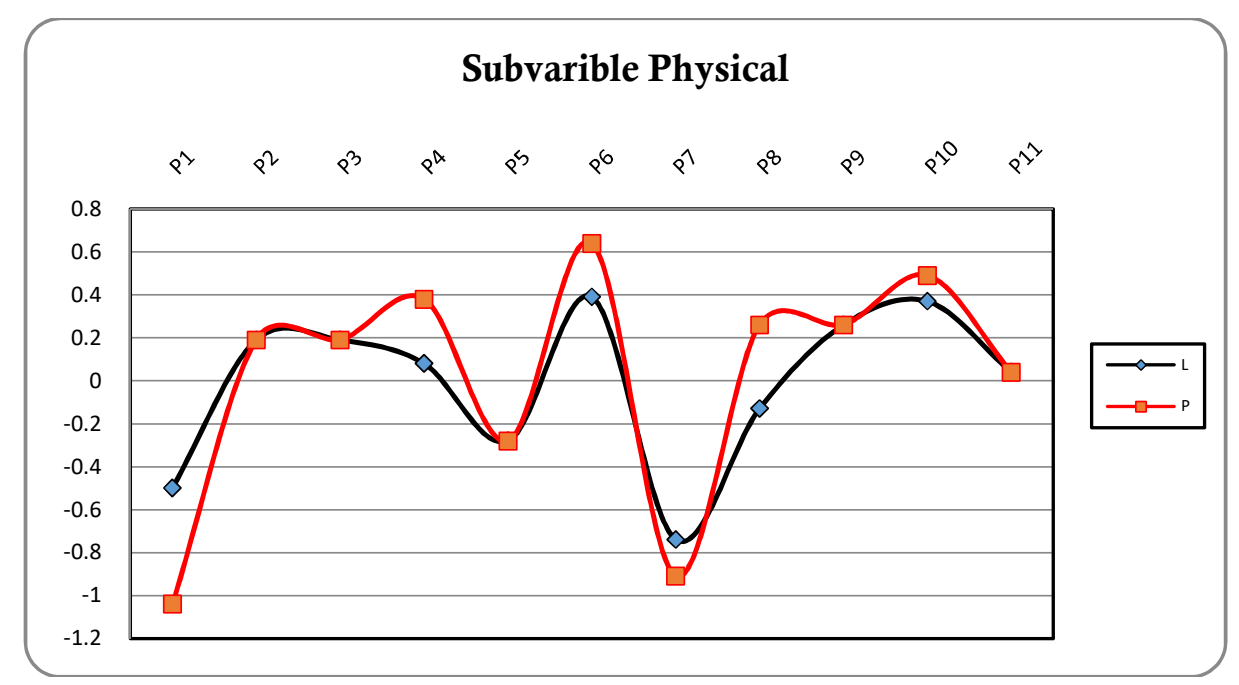

Figure 3. Differences in Physical Aggressive Behavior of Male and Female

Figure 3 above shows that male are more physically aggressive than female, male are more physically responsive than verbal. This was supported by research by Yuan et al. (2014) state that male are more physically aggressive than female. Physical aggressive behavior tends to be done by male, because male are not able to regulate emotions towards an event that occurs in the community, and male lack empathy for others in the community. So that men tend to lack prosocial behavior in the community, especially in people who need help, such as in the study of Zimmer-Gembeck, MJ, Geiger, \& Crick (2005) which revealed that there is a negative relationship between prosocial behavior and aggressive behavior. Whereas in research (Kokko, Tremblay, Lacourse, Nagin, \& Vitaro, 2006) suggest that aggressive physical behavior can contribute to acts of violence in schools that result in students dropping out of school.

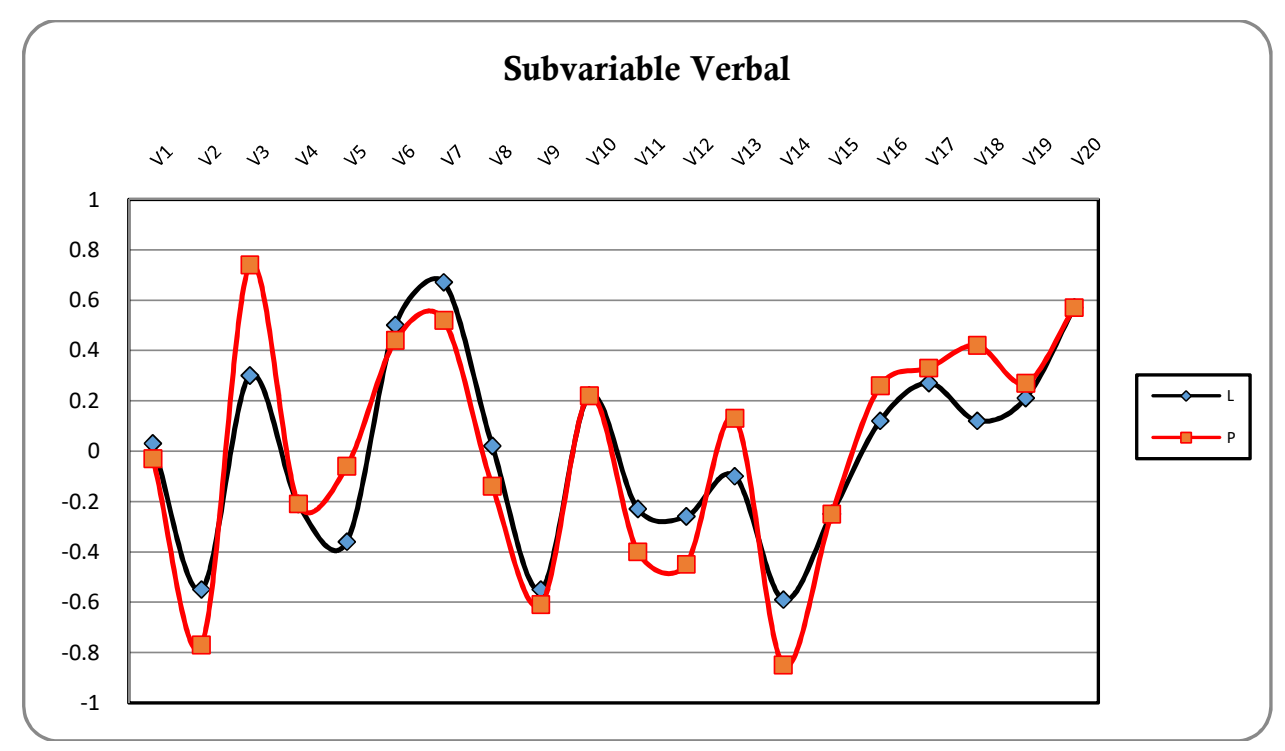

Figure 4. Differences in Verbal Aggressive Behavior of Male and Female 


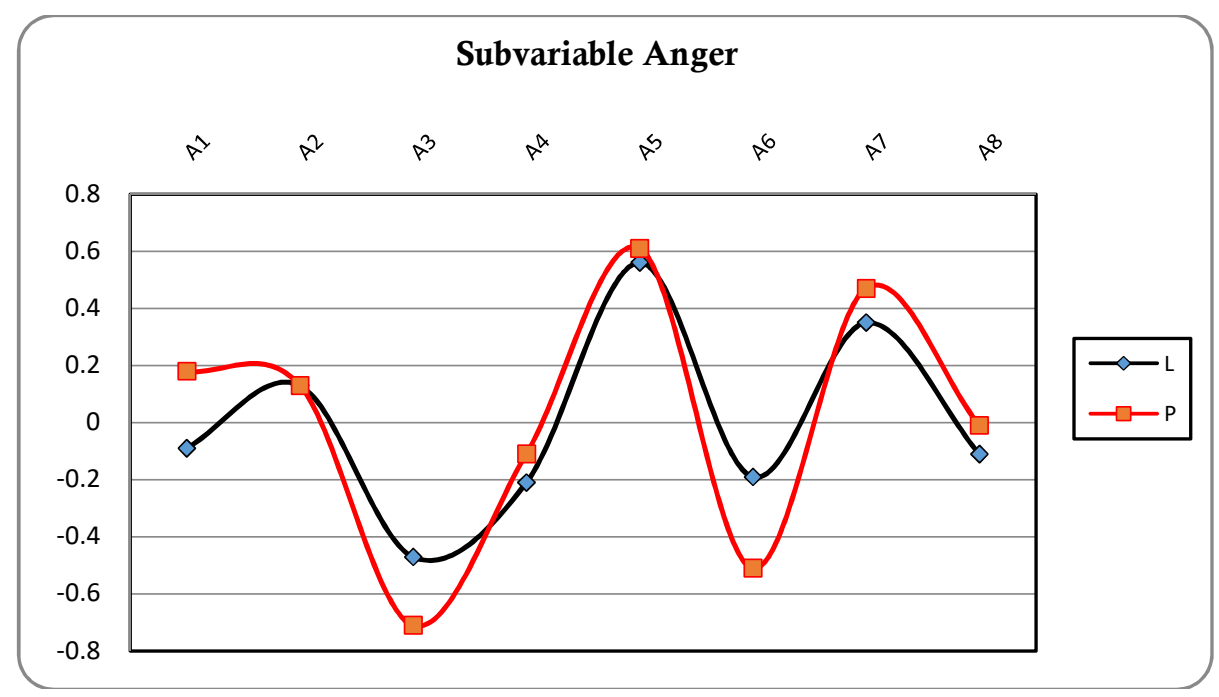

Figure 5. Differences in Aggressive Behavior Male and Female

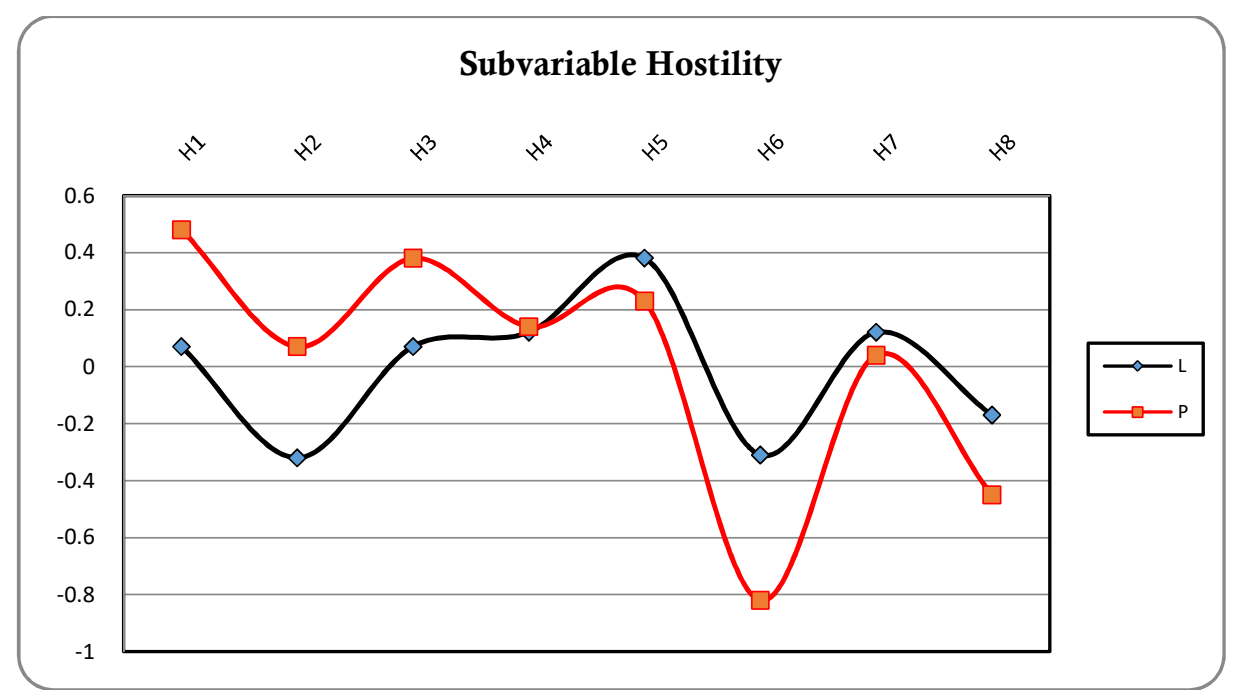

Figure 6. Differences in Aggressive Behavior of Male and Female

Figure 3 and Figure 4 above is confirmed by Baron \& Byrne (1994) that male students display more aggressive behavior in physical form. Whereas female, displaying aggressive behavior indirectly in the form of verbal (spreading gossip or isolating friends), this is clarified in Figure 4 which shows the tendency of female to conduct verbal aggressive behavior than male. In Figure 5, male are more aggressively aggressive than female, this is closely related to Figure 3, which states male are more physically aggressive than female. In figure 4 and figure 6 are interrelated on aggressive subvariable verbal and hostile. This is made clear by McAndrew's (2014) research that female are more prejudiced towards their friends, so female are more likely to use gossip as aggressive indirectly in verbal form than male. This does not mean that female are more aggressive than female in aggressive forms indirectly, only male and female differ in the aggressive style they like. However, it is possible for male to get involved in gossip when the situation demands to do so, and vice versa female can also be physically aggressive on certain occasions. This is supported by the findings shown in Figure 6, which show that male and female have the ability to respond aggressively to aggressive instruments in which there are two indicators: jealousy and prejudice.

The emergence of aggressive behavior among students requires attention from various parties, especially schools that are places of formal education. All parties in the school, namely subject matter teachers, counselors, and administrators have responsibilities and have an important role in handling this behavior (Lai, Ye, \& Chang, 2008). What happens is that the education applied so far seems to be more emphasis on efforts to improve students' cognitive abilities, compared to the affective development (Assegaf, 2004), giving rise to aggressive behavior found in students lately. Seeing this, it is necessary to identify the initial 
conditions of aggressive behavior of male and female students in junior high schools in West Sumatra. It aims to develop a model of guidance and counseling services in an effort to reduce the aggressive behavior of these students.

The results of the study which revealed a strategy to reduce aggressive behavior include improving the guidance and counseling services for students which can be organized via SMS messages (Rajabi, Ghasemzadeh, Ashrafpouri, \& Saadat, 2012), besides that teachers and parents can also play a role in providing understanding to students about school discipline and regulations in the direction and purpose of reducing violence (Barna \& Barna, 2014).

The findings of this study explain that in general male students are found to be more likely to behave physically aggressive, while female students are more likely to behave verbally aggressive. This finding is consistent with several previous studies regarding aggressive behavior in terms of gender (Carlo, Mestre, Samper, Tour, \& Armenta, 2010; Del Barrio, MV \& Carrasco, 2013; Diamantopoulou, Verhulst, \& van der Ende, 2011; Mestre, Samper, Frias, \& Tur, 2009).

\section{Conclusion}

These findings indicate a difference in aggressive behavior between male and female students in Junior High Schools in West Sumatra. In particular, the results of the study showed differences in the form of aggressive behavior between the two groups of samples, namely physically, verbally, and anger. Male students are found to be more likely to behave physically aggressive and show direct anger such as hitting, kicking, pushing, and insulting. Whereas female students are more likely to behave verbally aggressive with hurtful intentions such as; gossiping, exclusion, and bad prejudice. However, no differences were found in the fourth aggressive behaviour sub-variable, namely hostility which included two indicators; envy and prejudice between male and female students.

The limitation of this study is that the sample involved was not too large consisting of eight junior high schools in West Sumatera. In addition, variations in the instruments used have not focused on each aggressive behavior specifically.

\section{References}

Abd-El-Fattah, S. M. (2007). Is the aggression Questionnaire bias free? A Rasch analysis. International Education Journal, 8(2), 237-248.

Arifin, B. S. (2015). Psikologi Sosial. Bandung: Pustaka Setia.

Assegaf, A. R. (2004). Pendidikan Tanpa Kekerasan: Tipologi Kondisi, Kasus dan Konsep. Yogyakarta: Tiara Wacana.

Aulya, A., Ilyas, A., \& Ifdil, I. (2016). Perbedaan Perilaku Agresif Siswa Laki-Laki dan Siswa Perempuan. Jurnal EDUCATIO: Jurnal Pendidikan Indonesia, 2(1), 91-97.

Bandura, A. (1973). Aggression: A social learning analysis. Englewood Cliffs: Prentice-Hall.

Bandura, A. (1978). Social Learning Theory of Aggression. Journal of Communication, 28(3), 12-29.

Barna, I., \& Barna, O. (2014). The Effectiveness of School-based Violence Prevention Programs for Reducing Aggressive Behaviour. Procedia - Social and Behavioral Sciences, 137, 88-92. https://doi.org/10.1016/j.sbspro.2014.05.257

Baron, R. A., \& Byrne, D. (1994). Social psychology: understanding human interaction, (10th ed.), Allyn \& Bacon, A Division of Simon \& Schuster, Inc, Boston.

Berkowitz, L. (2005). Agresi I, Sebab dan Akibatnya. Terjemahan Hartati Woro Susiatni. Jakarta: Pustaka Binaman Pressindo.

Björkqvist, K. (2018). Gender differences in aggression. Current Opinion in Psychology, 19(17), 39-42. https://doi.org/10.1016/j.copsyc.2017.03.030

Bryant, F. B., \& Smith, B. D. (2001). Refining the Architecture of Aggression: A Measurement Model for the Buss-Perry Aggression Questionnaire. Journal of Research in Personality, 35(2), 138-167. https://doi.org/10.1006/jrpe.2000.2302

Burton, L. A., Hafetz, J., \& Henninger, D. (2007). Gender differences in relational and physical aggression. Social Behavior and Personality: An International Journal, 33(1), 41-50.

Buss, A. H., \& Perry, M. (1992). Personality Processes and Individual The Aggression Questionnaire. Journal of Personality and Social Psychology, 63(3), 452-459.

Card, N. A., \& Little, T. D. (2006). Proactive and reactive aggression in childhood and adolescence: A metaanalysis of differential relations with psychosocial adjustment. International Journal of Behavioral Development, 305), 466-480. https://doi.org/10.1177/0165025406071904

Card, Stucky, Sawalani, \& Little. (2008). Direct and indirect aggression during childhood and adolescence: A 
meta-analytic review of gender differences, intercorrelations, and relations to maladjustment. Child Dev, 79, 1185-1229.

Carlo, G., Mestre, M. V., Samper, P., Tur, A., \& Armenta, B. E. (2010). Feelings or cognitions? Moral cognitions and emotions as longitudinal predictors of prosocial and aggressive behaviors. Personality and Individual Differences, 48(8), 872-877. https://doi.org/10.1016/j.paid.2010.02.010

Casselman, R. B., \& Rosenbaum, A. (2014). Journal of Aggression , Maltreatment \& Fathers , Sons , and Aggression :A Path Model Adverse Childhood Experiences, Gender Roles, Developmental Issues And The Child Welfare System, (February 2015), 37-41. https://doi.org/10.1080/10926771.2014.904464

Cohn, A. M., Jakupcak, M., Seibert, L. A., Hildebrandt, T. B., \& Zeichner, A. (2010). The Role of Emotion Dysregulation in the Association Between Men's Restrictive Emotionality and Use of Physical Aggression. Psychology of Men \& Masculinity, 11(1), 53-64. https://doi.org/10.1037/a0018090

Creswell, J. W. (2013). Research design: Qualitative, quantitative, and mixed methods approaches. Sage publications.

Debono, A., Layton, R. L., Freeman, N., Muraven, M., Debono, A., Layton, R. L., ... Muraven, M. (2016). Understanding maladaptive responses to rejection: Aggression with an audience Understanding maladaptive responses to rejection: Aggression, 4545(April). https://doi.org/10.1080/00224545.2016.1165168

Del Barrio, M. V., \& Carrasco, M. A. (2013). Depresión en niños y Adolescentes [Depression in children and adolescents]. Madrid: Síntesis.

Denson, T. F., DeWall, C. N., \& Finkel, E. J. (2012). Self-control and aggression. Current Directions in Psychological Science, 21(1), 20-25. https://doi.org/10.1177/0963721411429451

Denson, T. F., Spanovic, M., Aviles, F. E., Pollock, V. E., Earleywine, M., \& Miller, N. (2011). The Effects of Acute Alcohol Intoxication and Self-Focused Rumination on Triggered Displaced Aggression. Journal of Aggression, Maltreatment \& Trauma, 20(2), 128-147. https://doi.org/10.1080/10926771.2011.546750

Dewi, K. S., Prihatsanti, U., Setyawan, I., \& Siswati. (2015). Children's Aggressive Behavior Tendency in Central Java Coastal Region: The Role of Parent-Child Interaction, Father's Affection and Media Exposure. Procedia Environmental Sciences, $23($ Ictcred $\quad 2014), \quad 192-198$. https://doi.org/10.1016/j.proenv.2015.01.030

Diamantopoulou, S., Verhulst, F. C., \& van der Ende, J. (2011). Gender Differences in the Development and Adult Outcome of Co-Occurring Depression and Delinquency in Adolescence. Journal of Abnormal Psychology, 120(3), 644-655. https://doi.org/10.1037/a0023669

Fischer, P., Kastenmüller, A., \& Greitemeyer, T. (2010). Media violence and the self: The impact of personalized gaming characters in aggressive video games on aggressive behavior. Journal of Experimental Social Psychology, 46(1), 192-195. https://doi.org/10.1016/j.jesp.2009.06.010

Fite, P. J., Stoppelbein, L., \& Greening, L. (2009). Proactive and reactive aggression in a child psychiatric inpatient population: Relations to psychopathic characteristics. Criminal Justice and Behavior, 36(5), 481-493. https://doi.org/10.1177/0093854809332706

Goldstein, S. E. (2016). Adolescents' Disclosure and Secrecy About Peer Behavior: Links with Cyber Aggression , Relational Aggression , and Overt Aggression. Journal of Child and Family Studies, 25(5), 1430-1440. https://doi.org/10.1007/s10826-015-0340-2

Harris, M. B. (1996). Aggressive experiences and aggressiveness: Relationship to ethnicity, gender, and age. Journal of Applied Social Psychology, 26(10), 843-870. https://doi.org/10.1111/j.15591816.1996.tb01114.x

Hasan, Y., Bègue, L., Scharkow, M., \& Bushman, B. J. (2018). Corrigendum to "The more you play, the more aggressive you become: A long-term experimental study of cumulative violent video game effects on hostile expectations and aggressive behavior" (J. Exp. Soc. Psychol. (2013) 49 (224227)(S0022103112002259)(10.10. Journal of Experimental Social Psychology, 74(2), 328. https://doi.org/10.1016/j.jesp.2017.08.009

Jerabeck, J. M., \& Ferguson, C. J. (2013). The influence of solitary and cooperative violent video game play on aggressive and prosocial behavior. Computers in Human Behavior, 29(6), 2573-2578. https://doi.org/10.1016/j.chb.2013.06.034

Keller, P. S., Blincoe, S., Gilbert, L. R., \& Haak, E. A. (2014). Journal of Aggression , Maltreatment \& Sleep Deprivation and Dating Aggression Perpetration in Female College Students : The Moderating Roles of Trait Aggression, Victimization by Partner, and Alcohol Use, (March 2015), 37-41. https://doi.org/10.1080/10926771.2014.896838

Kim, S., \& Nho, C. R. (2017). Longitudinal reciprocal effects between peer relationship difficulties and aggressive behaviors in Korean adolescents. Children and Youth Services Review, 83, 41-47. https://doi.org/10.1016/j.childyouth.2017.10.024

Ko, C. H., Yen, J. Y., Liu, S. C., Huang, C. F., \& Yen, C. F. (2009). The Associations Between Aggressive Behaviors and Internet Addiction and Online Activities in Adolescents. Journal of Adolescent Health, 44(6), 598605. https://doi.org/10.1016/j.jadohealth.2008.11.011 
Koeswara, E. (1998). Agresif Manusia. Bandung: Erasco.

Kokko, K., Tremblay, R. E., Lacourse, E., Nagin, D. S., \& Vitaro, F. (2006). Trajectories of prosocial behavior and physical aggression in middle childhood: Links to adolescent school dropout and physical violence. Journal of Research on Adolescence, 16(3), 403-428. https://doi.org/10.1111/j.15327795.2006.00500.x

Lai, S.-L., Ye, R., \& Chang, K.-P. (2008). Bullying in middle schools: An Asian-Pacific Regional study. Asia Pacific Education Review, 9(4), 503-515. https://doi.org/10.1007/BF03025666

Lee, E. J. (2014). The Relationship Between Unstable Self-Esteem and Aggression: Differences in Reactive and Proactive Aggression. Journal of Early Adolescence, 34(8), 1075-1093. https://doi.org/10.1177/0272431613518973

Lee, J., \& Randolph, K. A. (2015). Effects of parental monitoring on aggressive behavior among youth in the United States and South Korea: A cross-national study. Children and Youth Services Review, 55, 1-9. https://doi.org/10.1016/j.childyouth.2015.05.008

Lei, H., \& Li, S. (2018). Changes in aggression among Chinese adolescents from 2003 to 2015: A crosstemporal meta-analysis. Children and Youth Services Review, 1-38. https://doi.org/10.1016/j.childyouth.2018.07.033

Linacre, J. M. (2011). A User's Guide to WINSTEPS Ministeps Rasch-Model Computer Programs. https://doi.org/ISBN 0-941938-03-4

McAndrew, F. T. (2014). The "sword of a girls": Gossip and female aggression. Aggression and Violent Behavior, 19(3), 196-199. https://doi.org/10.1016/j.avb.2014.04.006

Mestre, M. V., Samper, P., Frias, M. D., \& Tur, A. M. (2009). Are wome more empathic than men? A longitudinal study in adolescence. The Spanish Journal of Psychology, 12(1), 76-83.

Park, J. H. (2006). Aggressor/victim subtypes and teacher factors in first grade as risk factors for later mental health symptoms and school functioning. Asia Pacific Education Review, 71$), 108-119$. https://doi.org/10.1007/BF03036789

Polman, H. (2008). Hot-Headed or cold-blooded? Towards a clear distinction between reactive and proactive aggression in youth. Netherlands: Prins Partners Ipskamp.

Rajabi, A., Ghasemzadeh, A., Ashrafpouri, Z., \& Saadat, M. (2012). Effects of Counseling by Mobile Phone Short Message Service (SMS) on Reducing Aggressive Behavior in Adolescence. Procedia - Social and Behavioral Sciences, 46, 1138-1142. https://doi.org/10.1016/j.sbspro.2012.05.263

Reyna, C., Ivacevich, M. G. L., Sanchez, A., \& Brussino, S. (2011). The Buss-Perry Aggression Questionnaire: Construct Validity and Gender Invariance Among Argentinean Adolescents. International Journal of Psychological Research, 4(2), 30-37.

Roll, J., Koglin, U., \& Petermann, F. (2012). Emotion Regulation and Childhood Aggression : Child Psychiatry \& Human Development, 43, 909-923. https://doi.org/10.1007/s10578-012-0303-4

Schober, G., Björkqvist, K., \& Somppi, S. (2009). Identifying a new subcategory of aggression: Sex differences in direct non-verbal aggression. Journal of Aggression, Conflict and Peace Research, 1(3), 58-70. https://doi.org/10.1108/17596599200900018

Segall, M. H., Berry, J. W., Poortinga, Y. H., \& Dasen, P. R. (1999). Cross-cultural psychology: Research and applications. Cambridge: Cambridge University Press.

Shi, W., Zhang, J., \& Huang, X. (2004). A study on junior middle school students' relationship qualities with their parents. Studies of Psychology and Behavior, 2(1), 328-332.

Singh, M. C., \& Singh, R. K. N. (2016). Aggression Between Men and Girls Inter School U-17 Footballers of Manipur. International Journal of Research-Granthaalayah, 4(1), 119-124.

Sumintono, B., \& Widhiarso, W. (2015). Aplikasi Pemodelan Rasch pada Assessment Pendidikan. Bandung: Trim Komunikata.

Taylor, S. E., Peplau, L. A., \& Sears, D. O. (2009). Psikologi Sosial Edisi Kedua Belas. Jakarta: Kencana Prenada Media Group.

Ticusan, M. (2014). Gender Difference and School Aggressiveness. Procedia - Social and Behavioral Sciences, 159, $128-131$.

Tull, M. T., Jakupcak, M., Paulson, A., \& Gratz, K. I. M. L. (2007). The role of emotional inexpressivity and experiential avoidance in the relationship between posttraumatic stress disorder symptom severity and aggressive behavior among men exposed to interpersonal violence. In Anxiety Stress and Coping (Vol. 20, pp. 337-352). https://doi.org/10.1080/10615800701379249

Værøy, H. (2013). Aggression questionnaire scores in extremely violent male prisoners, male bodybuilders , and healthy non-violent men. Open Journal of Psychiatry, 3, $293-300$. https://doi.org/10.4236/ojpsych.2013.33029

Van der Graaff, J., Branje, S., De Wied, M., \& Meeus, W. (2012). The Moderating Role of Empathy in the Association Between Parental Support and Adolescent Aggressive and Delinquent Behavior. Aggressive Behavior, 38(5), 368-377. https://doi.org/10.1002/ab.21435

Willis, S. (2010). Remaja dan Masalahnya. Bandung: Alfabeta. 
Yuan, C., Shao, A., Chen, X., Xin, T., Wang, L., \& Bian, Y. (2014). Developmental trajectory and gender differences in Chinese adolescents' physical and relational aggression: An analysis using the latent class growth model. Journal of Aggression, Conflict and Peace Research, 6(1), 44-55. https://doi.org/10.1108/JACPR-11-2012-0013

Zimmer-Gembeck, M. J., Geiger, T. C., \& Crick, N. R. (2005). Relational and physical aggression, prosocial behavior, and peer relations: Gender moderation and bidirectional associations. The Journal of Early Adolescence, 25(4), 421-452. 